\title{
Developing Ho Chi Minh City to be the city of affection, modernized, and quality living
}

\author{
Phan Thi Hong Xuan \\ HCMUSSH-Vietnam National University, Ho Chi Minh, Vietnam
}

\begin{abstract}
A Resolution made at the $10^{\text {th }}$ Communist Party of Vietnam's Congress has stated to "developing Ho Chi Minh City to be the City of affection, modernized, and quality living". This Resolution also reflects the cultural value of the City now a day because looking at the present of HCMC in the beginning of the XXI century, it is not very hard to feel of a city society that being developed, modernized and combination of new and old values, urban and rural, developing and contradiction. It is great challenge of how to manage the process of changing and adopting new living values of the City resident within jurisdictional rules, policies and law of the City government. This article will focus on analyzing the value of generations of "The Culture to Exist" and "The Culture to Develop" thru the perspective of urban Anthropology.
\end{abstract}

Keywords: mega city, ASEAN community, urban anthropology

\section{INTRODUCTION}

We are currently living in XXI century - a global urbanized century that, with UN's prediction, will develop many mega cities of more than 10 million residents per City in Asia Pacific area. Global urbanization has been created urbanized society, a symbol of human modernization with new, colorful, variety needs and demands. Urbanized society is also and symbol of the ideal living standards that people look forward to achieve. The poor and third-world countries must to become urbanized in order to be developed and industrialized.

In Vietnam, Ho Chi Minh City has been a major center City of the South Vietnam, the densest population of Vietnam and one of the top major Cities of the Asia Pacific area and the World. Ho Chi Minh City has tendency to become a Mega City in the future base on it's the geography, economy and population.

Approaching to Anthropology, urban is the place of communication, exchanging, observing and developing cultural values, also source of entertainment of individuals and families. Urban is also the center place of business development, gastronomy, global fashion, colorful music, international internet that most human being investing their time on currently (Mạc Đường 2016).

"Urbanized that characterized without uniformed and guidance results in different behaviors of the society. Urbanized will increase communication and relationship among groups of residents, also the local volunteer groups as well of people variety living styles." (Thêm 2015).

Focusing on the groups of residents, similar to other Cities of Vietnam and World... there are and more and more people moving from rural area to the big city, and it happens so fast that creates major effect to the lives of individual families and the whole country.

Table 1: List of people moving to Ho Chi Minh City thru period (people).

\begin{tabular}{ll}
\hline Time Frame & $\begin{array}{l}\text { Average people moving to the HCM } \\
\text { City per year }\end{array}$ \\
\hline $1984-1989$ & 27.154 \\
$1986-1990$ & 50.532 \\
$1994-1999$ & 86.753 \\
$1999-2004$ & 126.200 \\
\hline
\end{tabular}

The above table shows that the total people moving to HCM City in between 2009-2010 is almost the same at 1999-2004. Average each year the HCM 
City population increases about 200,000 people, among that is more than 130,000 people (Thanh 2017) come from other area. Currently, the HCM City population is more than 8 million. If included unregistered people and tourist, this would increase to 10 million people. The population density exceeds 25,000 people $/ 1 \mathrm{~km} 2$ (population density of Hong Kong and Singapore is only about 6,500 people/km2) (Nguyên 2017). If birth rate is the most important factor for the country population control, the moving rate of people to the City should be number one consideration of HCM City.

It is obvious that "Population is most important factor in the economy development of a local area and whole country. The population is a main core of creating wealth, materials of a society and also a subject of receiving wealth and living welfare. Standards of global population and its structure are the core of calculating and developing strategies of urban planning and economy planning for short-term and long-term goals". When he was alive, Ho Chi Minh pointed out the important of human resource in the development of the country "for the sake of 100 years, we should cultivate people". However, a dense population does not mean we have quality human resources.

Because the high speed of urbanization of HCM City in the years 90 of XX Century, the resident faced their own problems. It was giving them little time to adapt to the new city life, to change from rural, village culture to urbanized and modern city living, resulted in un-urbanized behaviors.

\section{RESEARCH METHODS}

The study applied descriptive research method using primary data of interview with subjects from ASEAN Community, and observation as well as secondary data from articles, newspaper, data center, books, and website.

This is the cause of important issues such as environment pollution, traffic congestion, flooding, robbery, and destroying value historical artifact items. In order for Ho Chi Minh City to surpass the population issue, we need to meet the goals to developing the City to become a Mega City with 4 Sub-mega cities. We will share with you the elements that related to culture development.

\section{RESULT AND DISCUSSION}

Let take a look at general cultures of the world, any nation that either has minor or major population, and categorized as uncivilized or civilized, has a mea- ningful and respectful culture because itself has conquered tough challenges of life to survive until now. To be survived in the future with other nations, each nation shall be maintained and developed the following elements (a) Mindful of United of the Nation, (b) Capability to adapt to changes of living society, (c) Mindset of Self-Control and self-surviving, (d) Organizing skill, leadership and clear vision of leaders of the nation, and (e) Peacefully get along with other nations.

About the mindful of United of the Nation element within the above described cultures, with lengthy history of urbanization beginning from mid of XVII Century, Saigon-Ho Chi Minh City Culture is a mix of local cultures that combined from the three Vietnam areas: North, Middle and South. In addition, old-time migration of people from 3 areas of China: Fukien, Guangdong, and Guangxi provinces also have significant contribution to the rich culture of Saigon. Other than that, the present of Indian community (more than 500 people) for more than 200 years contributes to the multi-cultures of Saigon - HCM City in the past and current. At present, besides the Kinh group, HCM City resident is characterized by 51 minority ethnic groups living together with 437,532 people, taking about $6.1 \%$ of the City population (Lệ Loan 2017). And this number is not included the new urbanized Cities like Phu My Hung and Thu Thiem the urbanizing process creates foreign communities that have high income, especially South Korean community of HCM City has almost 150.000 people.

About the capability to adapt of changes of living society element, the Mindset of Self-Control element and Self-Surviving, and the Management skills, leadership and vision of leaders of nation's elites. Let take a look thru an example of effective combination of these three elements in the space living of HCMC effected by the respectful Leader of the City: the General secretary of HCM City (later serves as General Secretary of the Communist Party of Vietnam), who had made a critical and effective Resolution, giving green light for HCM City to clear the barrier and open gates for new business - economy development "contribute to boost the country economy, escaping the challenged and dangerous economy crisis" in the years of 1980. (Speeches of Mr. Mai Chi Tho" (Phương 2015). This also proves the strong character to Saigoneers individually and the South of Vietnam people generally. If the people withdraw from challenges and not trying hard defeating difficulties, then there is no saying about the South Vietnam people characters such as "South Vietnam arriving early and leaving late", "Living together with flooding", "Challenges creating smartness". If there wasn't a changing experiment leading by the former 
Party General Secretary Nguyen Van Linh, who committed to take full responsibility for his action, in the year of 1980, Vietnam for now, still has not escaped the poorness if continue following down the path of old system of budget subsidies.

About the Peaceful way of living with other nations element. Objectively, we would like to include the letter from the late President Lee Kuan YewSingapore was sent in the morning of the date that our late Deputy Prime Minister Vo Van Kiet passed away (11/6/2008), the letter shows: "Mr. Kiet will be in people's memory". During the time Mr. Vo Van Kiet served as President of council of ministers and later as Deputy Prime Minister from 8/1991 to 9/1997, he was mentioned as a valuable, main person to push forward the revolution and reformation of the Vietnam communist party from 1986. He was a "project manager" of many challenged projects during the reformation time frame. In the foreign affair, we may say that Mr. Vo Van Kiet had placed important imprint in Vietnam foreign affair strategy such as improving the relationship with China, Europe, USA and joins ASEAN; push forward bilateral trading and multilateral trading with other countries Secretary Vo Van Kiet is a South Vietnamese, serving many public important roles of HCM City before joining the Government.

The Resolution made at the $10^{\text {th }}$ Communist Party of Vietnam's Congress, year of 2015-2020 has stated to "developing Ho Chi Minh City to be the City of affection, modernized, and quality living with resolutions. "developing democracy, law, and strength of solidarity of ethnic groups", Creating the dynamic improvement of quality growth and competition; Enhancing quality of foreign affair, Raising the sense of initiative in international integration; Developing cultures, training people, strongly investing and applying science - technologies is a jet engine to boost the economy-society, reforming education, and training system"

We are sure that missions and strategies to fulfill the above resolution is not out of the "culture to exist" logical reasoning but suitable with the complex, major urbanized HCM City compared to the whole country.

However, the global urbanization shows that every nation's dream is not limit at surviving but also ambitioning to become a leading nation of the world. This is the main driving force that motivates improvement and development of each individual and the whole society. A strong developed and stable society should be constructed base on selfmotivate of each individual contribution but not solo relying on the leader or the government. A welldeveloped culture shall contain the following elements (Thêm 2015), (1) Ambition construction the country to become powerful, leading of humanity civilization; (2) Capability to reform, accepting, controlling and defeating challenges; (3) Mind power of striving for better future of individual and community; (4) Leaders with straightforward and generous mind sets, have clear vision of the future, and absolutely independent of any dogmatism; (5) Capability of attraction other nations to create a united nation with unified ideal, and future.

I would like to discuss the above element of number (10), the "Capability of attraction other nations to create a strong alliance with unified ideal, and future". HCM City has been leading the whole nation about developing the foreign affair. When Vietnam joins ASEAN in 1995, the City Committee had decided to establish a Vietnam - Southeast Asian Friendship Association (HVAFA) - belonged HCMC Union of Friendship Organizations. This is one of the earliest associations established in the whole country compared with VAFA that was established 2011. This is a proof of leading capability of HCM City in many fields, including foreign affair. Other country leaders, especially ASEAN country leaders, when visiting Vietnam always schedule to meet with HCM city leaders during the official journey. Currently, on 21/3/2017 HCM City Committee Leader Nguyen Thanh Phong meets with Singapore President Lee Hsien Loong and his team. During the meeting, Mr. Nguyen Thanh Phong has insisted the coherent policies of Vietnam is to cooperating with Singapore in both bilateral and multilateral for unified benefit and peace of the two countries. The City Government always improves to create opportunities for investment and business development, especially Singapore (Đăng 2017).

Other elements of "Culture to develop" has been mentioned in the "Culture to exist", we would like to discuss more in the element number (6) base on the event that HCM City formally establishing the "Program of Youth Enterprise, Developing HCM City City of Youth Enterprise" (2016) to create opportunities for the youth developing creativity and reforming as well as discussing ideologies with community to change the "impossible" to "capable", helping to develop the local economy. The important ideal of "City of Youth Enterprise" is the ecosystem of Startup business with unite network and supportive each other to success.

Besides, we see that the element number (9) is similar with the ideal develop goals of HCM City: civilized, urbanized and affection. Obviously, despite the fact of tremendous increasing the amount of people migrate to HCM City, the City Government still continued creating subsistence opportunities for the City residents. Doctor Tran Thanh Long - President of Low Income Patient Supportive Group pro- 
poses to "develop the new typical culture values" to nurture and develop the nation human culture, activate the tradition "supportive each other", "the leaves protect tattered ones", and "love other like loving yourself" of the society. It is fact that there are more and more people stepping up with compassionate and kind hearts. They set good examples of behaviors in social programs and charity activities, creating warm-hearted and love environment and light up the great humanism, contribute in creating new value of culture, represent the typical character of the Vietnamese; living with affection, living for the community, for the civilized society, a unique society with Democracy.

Doctor Quan, representative of HCM City Committee proposes: develop HCM City with intellectual resources. It is time to act to use intellectual and economy resources to come up with effective resolution to develop the City to become civilized and modernized. The important is to reform the mindset of people, focus on resolutions to solve the issue instead of explaining challenges of the issue-solving process. By doing that, we then could be proud of residents of HCM City, always leading the country to develop a civilized and modernized society.

\section{CONCLUSION}

In order to HCM City to be developed to higher level and become one of top urbanized City of Vietnam and local area and to fulfil the goal "developing HCM City with quality living, civilized, modernized and affection", besides urban planning and infrastructure construction, we need to focus on developing a system of culture values including the Culture to Exist and Culture to Develop.

Culture is a fruit of human achievement, a corollary of human revolution. It's interesting that about $40 \%$ of people living in HCM City still don't think that they are actually part the City resident but just temporary living in the City. Because of this mindset "this City is not mine", they are often careless and don't participate in activities that contribute developing the City civilization and modernization. Among them, there are people just migrate to the City for studying and work but also there are people who already living more than 10 years in the City and still, not following the law when participating in traffic flow, litter in the roadway, ditches and streams, spitting in public... Mr. Jonathan Hanh Nguyen - Vietnamese Filipino has shared his thought "Civilized human is a must to develop the economy" (Anh 2016). We sure that urbanized City issues must be strictly resolved by law to create a clean City. Only establishing roadway cleaning worker is not enough, but we must have other measures to self-motivate the people to have conscious of civilization, not litter indiscriminately and rushing in traffic.

In addition, HCM City should focus on utilizing and maximizing the capability of the City to develop the Economy System, improve the resident living quality per the country goals of the development in ASEAN Communities "Forging Ahead Together", Vision of 2025 (Announcement of Kuala Lumpur 2015).

\section{REFERENCES}

Anh T. 2016. Xây dựng TPHCM có chất lượng sống tốt, văn minh, hiện đại, nghĩa tình (http://sggp.org.vn/chinhtri/2016/2/411419/\#sthash.qJxQ7 Wuj.dpuf (truy cập 10/04/2017)

Diển Bách T.K. 1994. tập I, Hà Nội, Việt Nam: 815.

Đường M. 2016. Môi trường văn hóa đô thị hiện đại, NXB Khoa học Xã hội, TP.HCM: 10

Loan L. 2017. Đồng bào các dân tộc thiểu số ở TPHCM: Hộ nghèo giảm, hộ khá - giàu tang. https://voh.com.vn/tin-tpho-chi-minh/dong-bao-cac-dan-toc-thieu-so-o-tphcm-hongheo-giam-ho-kha-giau-tang-224960.html).

Nghĩa N.T. \& Giang N.T.H. 2016. Toàn cầu hóa, hội nhập quốc tế và giữ gìn, phát huy giá trị truyền thống của dân tộc Việt Nam (sách chuyên khảo). NXB Chính Trị Quốc gia, Hà Nội.

Nguyên N.H. 2017. Giao thông nội đô thành phố Hồ Chí Minh vượt qua nhiều trở lực để phát triển, trên trang: (http://css.hcmussh.edu.vn/?ArticleId=27320807-49ad4f7f-9eba-157946a150c9, truy cập ngày 22/3/2017).

Phương H.. 2015. Nguyễn Văn Linh - người thiết kế công cuộc đổi mới. http://vnexpress.net/tin-tuc/thoi-su/nguyen-vanlinh-nguoi-thiet-ke-cong-cuoc-doi-moi-3239782.html.

Phương T. \& Đăng N. 2017. Thủ tướng Lý Hiển Long thăm TP.HCM, http://tuoitre.vn/tin/the-gioi/20170321/thu-tuongly-hien-long-tham-tphcm/1283975.html.

Thành L.V. 2017. Đô thị hóa và vấn đề dân nhập cư ở TP.HCM, trên trang: http://thienthu.weebly.com/uploads/4/8/6/9/4869850/dothih oatphcm.pdf, truy cập ngày 22/3/2017.

Thêm T.N. 2015. Một số vấn đề về hệ giá trị Việt Nam trong giai đoạn hiện tại. 